\title{
Evaluation of Updated Therapeutic Options For COVID-19 in Pregnancy and Lactation
}

\section{Gebelikte ve Emzirme Döneminde COViD-19 Güncel Tedavi Seçeneklerinin Değerlendirilmesi}

(D) Zeynep TIRMIKÇIOĞLU

İzmir Atatürk Training and Research Hospital, Department of Clinical Pharmacology and Toxicology, İzmir, Turkey

\begin{abstract}
A new respiratory tract infection caused by coronaviruses was identified in 2019 and called Coronavirus disease-19 (COVID-19). It has long been known that pregnant women are not more susceptible to viral illness. However, changes to their immune system in pregnancy can be associated with more severe symptoms. Pregnant women do not seem to be at higher risk than non-pregnant individuals of severe COVID-19 infection. There are currently no data suggesting an increased risk of miscarriage or malformations in relation to coronaviruses. There is no specific antiviral treatment for COVID-19. Therapeutic options for patients with confirmed COVID-19 have been recently updated as hydroxychloroquine and/or azithromycin, and favipiravir for severe pneumonia. According to updated national treatment guidelines for COVID-19, favipiravir is not recommended for use in pregnant or breastfeeding women, but lopinavir/ritonavir can be used as second-line therapy. Published experience with COVID-19 during breastfeeding is limited. The main risk of breastfeeding is the close contact between mother and baby. This paper presents a literature review regarding outcomes after use of hydroxychloroquine, azithromycin and lopinavir/ritonavir during pregnancy and lactation. Hydroxychloroquine and/or azithromycin use is not expected to increase the risk of birth defects and adverse effects in breastfed infants. Based on reports of human immunodeficiency virus- infected women, lopinavir/ritonavir use does not appear to increase the risk of adverse effects, and it may be chosen in life-threatening situations. It is important to pay special attention to the selection of drugs for COVID-19 and utilize the most up-to-date information to optimize outcomes for both infant and mother.
\end{abstract}

Keywords: COVID-19, drug, pregnancy, lactation

\section{ÖZ}

2019 yilında koronavirüslerin yol açtığı yeni tip bir viral solunum yolu enfeksiyonu tanımlanmış ve bu enfeksiyon Koronavirüs hastalığı-19 (COVID-19) olarak isimlendirilmiştir. Gebe kadınların viral hastalıklara daha yatkın olmadıkları uzun zamandır bilinmektedir. Ancak gebelikte bağışıklık sisteminde meydana gelen değişiklikler, gebelerin bu hastalıkları daha ağır bulgularla geçirmelerine neden olabilir. Ağır COVID-19 enfeksiyonu geçiren gebe olmayan kadınlarla karşılaştırıldıklarında gebe kadınlar, daha fazla risk altında gözükmemektedirler. Bugün için koronavirüslerin düşük, erken gebelik kaybı veya doğumsal defektlerle bir ilişkisi olduğuna dair kanıt yoktur. COVID-19'un spesifik antiviral bir tedavisi bulunmamaktadır. COVID-19 tanısı almış hastalarda tedavi seçenekleri son olarak, hidrosiklorokin ve/veya azitromisin, ağır pnömoni olgularında favipiravir olarak güncellenmiştir. Güncellenmiş COVID-19 ulusal tedavi kılavuzuna göre, favipiravirin gebelerde ve emziren annelerde kullanımı önerilmemektedir. Lopinavir/ritonavir alternatif ya da kombine tedavi olarak diğer ilaçlara yanıt vermeyen gebelerde tercih edilebilir. Emzirme döneminde COVID-19 ile ilgili yayınlanmış veriler sınırlıdır. Emzirmede esas risk, damlacık yoluyla hastalığı bulaştırabilecek anne ile bebeğin yakın temasıdır. COVID-19 tedavisinde kullanılacak ilaçlar, fetus ve yenidoğana olası advers etkileri açısından dikkatle değerlendirilmelidir. Bu derleme gebelikte ve emzirme döneminde hidroksiklorokin, azitromisin ve lopinavir/ritonavir kullanımına ait literatür bilgisini sunmaktadır. Gebelikte ve emzirme döneminde hidroksiklorokin ve azitromisin kullanımının doğumsal kusur riskini artırması ya da yenidoğanda advers etkiye yol açması beklenmemektedir. Lopinavir/ritonavir tedavisi ile ilgili bilgilerimiz insan bağısııklık yetmezliği virüsü enfeksiyonu olan gebelere ait olmakla birlikte anne sağlığını tehdit eden durumlarda hem gebelikte hem emzirme döneminde bu ilaçlar kullanılabilir. Gebe veya emziren kadınlarda COVID-19 enfeksiyonunu değerlendirmek zor olabilmekle birlikte ilaç seçimi konusunda özellikle dikkatli olunmalı ve hem anne hem bebek açısından ideal sonuçlar için en güncel bilgiler kullanılmalıdır.

Anahtar Sözcükler: COVID-19, ilaç, gebelik, emzirme
*This work was supported by UpToDate.

Address for Correspondence: Zeynep TIRMIKÇIOĞU, İzmir Atatürk Training and Research Hospital, Clinic of Clinical Pharmacology and Toxicology, İzmir, Turkey

E-mail: dr.zeynebfarma@gmail.com ORCID ID: orcid.org/0000-0002-5639-4665

Cite this article as: Tırmıkçıoğlu Z. Evaluation of Updated Therapeutic Options For COVID-19 in Pregnancy and Lactation. Bezmialem Science. 2021;9(Supplement 1):78-83.

${ }^{\circ}$ Copyright 2021 by the Bezmiâlem Vakıf University

Bezmiâlem Science published by Galenos Publishing House.
Received: 20.05 .2020

Accepted: 15.06 .2020 


\section{Introduction}

Coronaviruses $(\mathrm{CoV})$ are a family of viruses that can cause various degrees of respiratory, gastrointestinal, liver, kidney damage and neurological damage in humans and animals. They can cause different clinical outcomes from the common cold to more serious diseases such as Middle East respiratory syndrome (MERS) and severe acute respiratory syndrome (SARS) (1).

The number of people infected by the new $\mathrm{CoV}$, which has become a global problem in 2020, is today expressed in millions. Since it was first reported in 2019 in Wuhan, China, as a result of the examination of cases of pneumonia of unknown etiology, this virus-related disease defined as "2019-nCoV" is called Coronavirus disease-19 (COVID-19). COVID-19, an infection with respiratory symptoms, fever, cough and dyspnoea, can cause pneumonia, severe acute respiratory infection, kidney failure and even death in more severe cases.

It has long been known that pregnant women are not more prone to viral diseases. However, changes in the immune system during pregnancy may cause pregnant women to experience these diseases with more severe symptoms. However, to date, there is no evidence that pregnant women are more susceptible to COVID-19 infection, or that those with COVID-19 infection are more likely to develop more severe pneumonia (2).

No malformation has been reported in babies born to pregnant women with coronavirus infection. Although some neonatal complications have been reported that may be associated with SARS and MERS infections, data on COVID-19 infection are still limited. According to the reports of 9 pregnant women who gave birth at 29-36 weeks of gestation with COVID-19 infection, no health problem occurred in babies, and no coronavirus was detected in amniotic fluid and milk samples (3). Although all women have given birth by cesarean section, no reason has been presented for the need for a cesarean section except for the presence of COVID-19 infection. Three of the babies born weigh less than 2500 grams and this has been associated with prematurity and preeclampsia. In another case report, 10 babies born from 9 women with COVID-19 pneumonia were observed, and 6 babies, including twins, were born preterm and had respiratory symptoms (4). A 35-week-old baby died of multiple organ failure; The coronavirus tests of 9 babies tested were negative. Published information on COVID-19 and breastfeeding is very limited. Researchers who conducted systematic reviews reported that no virus was found in measurements made on the milk of 13 mothers with COVID-19 infection. However, it should be kept in mind that this number is not sufficient to interpret the results (5).

Currently, there is no specific treatment for COVID-19 with proven safety and effectiveness. In patients with a confirmed diagnosis of COVID-19, antibacterials other than azithromycin are discontinued unless there is clinical or laboratory evidence of the presence of an additional bacterial pathogen. Hydroxychloroquine is also added to the treatment in patients with suspected viral pneumonia (1). Although it was in the treatment plan in the first months when the infection started to spread, according to the treatment guideline of the Ministry of Health, oseltamivir is no longer used in treatment in patients whose diagnosis of influenza pneumonia has been ruled out $(1,6)$. Favipiravir has been defined as an additional treatment option in patients with severe pneumonia who do not respond to the first treatment. According to the updated treatment options, use of hydroxychloroquine or lopinavir/ritonavir in pregnant women with a definite diagnosis of COVID-19 was deemed appropriate (Table 1). Although a treatment protocol for breastfeeding mothers has not been specified, it has been reported that favipiravir should not be used in pregnant women and nursing mothers (1).

The aim of this review is to re-evaluate the updated treatment options for COVID-19 and to provide detailed literature on the use of hydroxychloroquine, azithromycin, and lopinavir/ ritonavir therapy in pregnancy and breastfeeding.

\section{Use of Hydroxychloroquine in Pregnancy and Breastfeeding}

The results of different studies and case reports about hydroxychloroquine are that the use of this drug during pregnancy does not increase the risk of congenital anomalies (7-9). Based on some experimental studies and case reports that hydroxychloroquine use during pregnancy may cause problems in vision and hearing functions in born babies, large-scale studies have been conducted on these defects (10). Children who were exposed to hydroxychloroquine in their mother's womb were followed up and no visual or hearing problems were found in their examinations $(11,12)$. A 2011 systematic review concluded that there is no evidence that the use of chloroquine or hydroxychloroquine during pregnancy causes ocular toxicity (13).

In another study in which clinical studies conducted between 1980 and 2007 were compiled, it was reported that the use of hydroxychloroquine in pregnant women with autoimmune disease was not associated with congenital defects, miscarriage, stillbirth or preterm birth (14). Another meta-analysis published in 2015 reached similar conclusions; however, some increase in the risk of spontaneous abortion has been reported. The significant increase in the risk of miscarriage was thought to be due to the mother's autoimmune disease rather than hydroxychloroquine (15). The literature suggests that hydroxychloroquine should not be discontinued during and after pregnancy to prevent exacerbation of autoimmune diseases. In the European League Against Rheumatism (EULAR) report published on the use of antirheumatic drugs during pregnancy in 2016, it was stated that hydroxychloroquine treatment does not increase the risk of congenital malformations according to the available evidence; It has been recommended to continue using hydroxychloroquine in symptomatic patients during pregnancy (16).

Hydroxychloroquine is also recommended for malaria prophylaxis in pregnant women who have to travel to endemic areas. Since it is thought that malaria, which progresses badly 
Table 1. COVID-19 Adult Patient Treatment Options *

\begin{tabular}{|c|c|c|}
\hline Name of the drug & Daily dose/administration & Duration of medication (day) \\
\hline \multicolumn{3}{|c|}{ Treatment in uncomplicated possible/definite diagnosed COVID-19 cases } \\
\hline $\begin{array}{l}\text { Hydroxychloroquine } 200 \mathrm{mg} \text { tablet } \\
-/+\end{array}$ & $2 \times 200 \mathrm{mg}$ tablet, oral & 5 day \\
\hline Azithromycin & $\begin{array}{l}\text { First day, } 500 \mathrm{mg} \text { tablet, oral } \\
\text { Following } 4 \text { days } 250 \mathrm{mg} / \text { day }\end{array}$ & 5 day \\
\hline Azithromycin & $\begin{array}{l}\text { First day, } 500 \mathrm{mg} \text { tablet, oral } \\
\text { Following } 4 \text { days } 250 \mathrm{mg} / \text { day }\end{array}$ & 5 day \\
\hline $\begin{array}{l}\text { Favipiravir } \\
200 \mathrm{mg} \text { tablet } \\
-/+\end{array}$ & $\begin{array}{l}2 \times 1600 \mathrm{mg} \text { loading } \\
2 \times 600 \mathrm{mg} \text { maintenance }\end{array}$ & 5 day \\
\hline Azithromycin & $\begin{array}{l}\text { First day, } 500 \mathrm{mg} \text { tablet, oral } \\
\text { Following } 4 \text { days } 250 \mathrm{mg} / \text { day }\end{array}$ & 5 day \\
\hline \multicolumn{3}{|c|}{$\begin{array}{l}\text { Treatment in patients whose clinical condition is aggravated or whose pneumonia symptoms progress while receiving hydroxychloroquine } \\
\text { treatment }\end{array}$} \\
\hline Favipiravir & $2 \times 1600 \mathrm{mg}$ loading & \\
\hline $\begin{array}{l}200 \mathrm{mg} \text { tablet (hydroxycoloquine treatment should be } \\
\text { completed to } 10 \text { days and discontinued }\end{array}$ & $2 \times 600 \mathrm{mg}$ maintenance & 5 day \\
\hline
\end{tabular}

due to the decrease in cellular responses during pregnancy, will harm pregnancy much more, the use of hydroxychloroquine in mandatory situations has been accepted as safe (17).

Babies exposed to hydroxychloroquine during breastfeeding receive only a very small amount of the drug that passes into breast milk (18-20). It has been reported that babies of mothers who take hydroxychloroquine in doses of 200-400 mg per day may be exposed to $0.06-0.2 \mathrm{mg} / \mathrm{kg}$ drug with breast milk (21). No drug-related adverse effects in terms of growth, vision and hearing functions were found in babies whose development was followed up to the age of one (22-24). Hydroxychloroquine is considered to be acceptable for use during breastfeeding.

It has also been reported that the infants of mothers who took hydroxychloroquine once a week due to malaria prophylaxis, the amount of the drug in the milk that would not harm the baby, but did not protect the baby against malaria (25). Therefore, when malaria prophylaxis is required, breastfed babies should also take hydroxychloroquine at recommended doses.

\section{Lopinavir/Ritonavir Use During Pregnancy and Breastfeeding}

Exposure to protease inhibitors during pregnancy is not thought to cause an increased risk of congenital anomalies. Although adverse pregnancy outcomes were reported in the studies, they were observed in fewer and mostly premature babies.

In a study comparing the concentrations of protease inhibitors in maternal and cord blood, it was reported that these drugs did not exceed the placenta at term (26). In 2009, it was found that lopinavir was not in measurable concentrations in cord blood in samples taken from 26 human immunodeficiency virus (HIV)infected pregnant women (27). As a result of the fact that some drug solutions contain propylene glycol and premature babies cannot eliminate this substance, kidney and respiratory problems have occurred in some premature babies. In a study reported from France in 2011, it was observed that adrenal dysfunction developed in babies of HIV-infected mothers who took lopinavirritonavir at birth and for an average of 30 days (28). All term babies born at term are asymptomatic; however, it was reported 
that three of the preterm babies showed signs of dangerous adrenal insufficiency such as hyponatremia and hyperkalemia and cardiogenic shock developed in one premature baby. All adverse findings resolved after cessation of lopinavir-ritonavir exposure. Researchers also stated that these findings in premature babies may have occurred due to propylene glycol toxicity (28).

According to thousands of pregnancy data collected until 2019, the rate of congenital malformation in pregnant women who received lopinavir for HIV treatment is around $2.1 \%$, which is similar to the general population (29). No increase in the risk of congenital defects was observed in pregnancies using lopinavir, 1333 of which were in the first trimester and 2371 in the second trimester (30). According to UK and Ireland national data, 134 babies with congenital defects were born out of 4864 pregnancies using lopinavir; the congenital anomaly rate is $2.9 \%$ (31). The defects reported by the researchers, who stated that there is no difference in anomaly rates between those who started the drug in the first trimester and afterwards, include limb deficiencies, heart defects, musculoskeletal defects, chromosomal abnormalities and urinary system defects. However, the rate of congenital anomalies reported in this study is not higher than the expected rate in the general population. Another study investigating the effects of lopinavir in different periods during pregnancy concluded that first trimester drug exposure may be associated with preterm delivery compared to late use (32).

Data on lopinavir and ritonavir treatment have been obtained from pregnant women and mothers with HIV infection. Accordingly, breastfeeding in HIV-infected mothers in many developed countries is restricted by the thought that the infection can be transmitted to the baby through milk. The World Health Organization (WHO) recommends that antiretroviral therapy be continued in a way that minimizes the risk of transmission of infection from mother to baby in countries where adequate and acceptable nutrition opportunities are not available instead of breast milk; However, there is no lopinavir-ritonavir among the treatment options recommended by WHO (33). Therefore, observational data on the use of lopinavir and ritonavir in lactation are very limited.

Lopinavir passes into breast milk in small amounts (34). In a study conducted with HIV-positive women, the average amount in breast milk was found to be $4263 \mathrm{mcg} / \mathrm{L}$ (35). In this study, 9 HIV-positive pregnant women received 3 doses of lopinavir $(200 \mathrm{mg})$, ritonavir $(150 \mathrm{mg})$, zidovudine $(300 \mathrm{mg})$, lamivudine $(50 \mathrm{mg}$ ) before cesarean section, 3 hours apart of each, and milk samples were collected at a mean postpartum $25^{\text {th }}$ hour. Mean ritonavir levels measured in breast milk in the same study were $240 \mathrm{mcg} / \mathrm{L}$. According to the results of an observational study conducted in breastfed infants, no adverse effects were observed at 1,3 and 6 months in babies whose mothers received lopinavir $(400 \mathrm{mg})$ and ritonavir $(100 \mathrm{mg})$ twice daily as part of the HIV infection treatment (36).

\section{Use of Azithromycin in Pregnancy and Breastfeeding}

Based on experimental animal studies and human reports, the use of azithromycin during pregnancy is not expected to increase the risk of birth defects. In 21 human placentas where transplacental transmission was evaluated, it was reported that less than $3 \%$ of the maternal azithromycin dose passed to the fetal compartment (37).

In case reports and retrospective studies reporting the results of more than a thousand pregnant women who received azithromycin for the treatment of chlamydia infection, no risk of pregnancy complications and congenital defects was reported (38-40). According to the data of the Israel Teratogenicity Information Service published in 2012, no increase in the risk of major congenital malformation or cardiovascular defect was detected in 156 pregnant women exposed to azithromycin, 119 of which were in the first trimester (41). In a study examining 1459 children whose mothers used azithromycin during their pregnancy, no increase was identified in terms of congenital defects (42). In a study investigating the relationship between the use of antibiotics during pregnancy and spontaneous abortion in 2017, it was reported that azithromycin use may be associated with abortions (43).

Since azithromycin passes into milk in small amounts, it is not expected to have adverse effects in breastfed babies. Measurement and standardization of azithromycin levels in breast milk is difficult due to its slow clearance and accumulation. It has been reported that after $500 \mathrm{mg}$ of oral azithromycin intake per day, breast milk concentrations increased to $1.3 \mathrm{mg} / \mathrm{L} 1$ hour after the first dose and $2.8 \mathrm{mg} / \mathrm{L} 30$ hours after the third dose (44). The amount that the baby can receive through breast milk has been calculated as approximately $0.5 \mathrm{mg} /$ day.

If the mother is using azithromycin during the breastfeeding period, it should be monitored whether there are possible gastrointestinal findings such as candidiasis, vomiting, and diarrhea. Although there are studies reporting the risk of infantile hypertrophic pyloric stenosis in babies of mothers who used macrolides in the first two weeks of breastfeeding, the relation of this situation with drug use is highly doubtful $(45,46)$. In a study conducted on babies whose mothers used macrolide and breastmilk, no relationship was found between pyloric stenosis and macrolide use (47). In this study, it was reported that the use of azithromycin during breastfeeding was present in 10 out of 55 mothers, and a comparison was made with the use of amoxicillin in terms of adverse effects. Accordingly, the rate of adverse reactions in infants exposed to macrolide was $12.7 \%$, while this rate was similar to the adverse reaction rate seen in infants exposed to amoxicillin through breast milk. Reactions observed in infants include rash, diarrhea, decreased appetite, and tendency to sleep. It was reported that no adverse effects were observed in babies breastfed by eight mothers who were given $500 \mathrm{mg}$ intravenous azithromycin at 15, 30 and 60 minutes prior to cesarean section (48). In two meta-analyzes reported in 2019 , it was concluded that there was no relationship between macrolide use during breastfeeding and infantile hypertrophic pyloric stenosis $(49,50)$.

\section{Result}

COVID-19 treatment options during pregnancy and breastfeeding should be carefully evaluated in terms of possible 
risks and the patient should be informed. Following this evaluation and information, some medications administered to other adult individuals can also be used in the treatment of the pregnant patient in cases where medication is necessary. A risk assessment that is satisfactory for both the follow-up clinician and the patient, with detailed literature information, can also reduce anxiety related to the disease and possible drug use. The use of hydroxychloroquine and azithromycin during pregnancy and lactation is not expected to increase the risk of birth defects or cause adverse effects in the newborn. Although our information about lopinavir/ritonavir treatment belongs to pregnant women with HIV infection, these drugs can be used both during pregnancy and breastfeeding in situations that threaten maternal health. There is always a need for large-scale epidemiological studies to evaluate the effects of drugs used in the treatment of COVID-19 during pregnancy and lactation. Although COVID-19 is a disease full of unknowns for today, it is the duty of health professionals to provide treatment options to pregnant and breastfeeding mothers with an approach that takes into account both maternal health and baby's health in the light of current information.

Peer-review: Externally peer reviewed.

Financial Disclosure: This work was supported by UpToDate.

\section{References}

1. T.C. Sağlık Bakanlığı. COVID-19 erişkin hasta yönetimi ve tedavisi, 2020. Last Accessed Date: 15.05.2020. Available from: https://covid19bilgi.saglik.gov.tr/depo/tedavi/COVID19EriskinHastaTedavisi.pdf.

2. Gebelik, doğum ve lohusalık döneminde "Yeni koronavirüs enfeksiyonu 2019” (COVID-19) hakkında Türk Perinatoloji Derneği görüşü, 2020. Last Accessed Date: 15.05.2020. Available from: http://www.perinatoloji.org.tr/gebelik-dogum-ve-lohusalikdoneminde-yeni-koronavirus-enfeksiyonu-2019-covid-19-hakkindaturk-perinatoloji-dernegi-gorusu.

3. Chen H, Guo J, Wang C, Luo F, Yu X, Zhang W et al. Clinical characteristics and intrauterine vertical transmission potential of COVID-19 infection in none pregnant women: A retrospective review of medical records. Lancet 2020;395:809-15.

4. Zhu H, Wang L, Fang C, Peng S, Zhang L, Chang G, et al. Clinical analysis of 10 neonates born to mothers with 2019-nCoV pneumonia. Transl Pediatr 2020;9:51-60.

5. Rodrigues C, Baía I, Domingues R, Barros H. Pregnancy and breastfeeding during COVID-19 pandemic: A systematic review of published pregnancy cases. Front Public Health 2020;8:558144.

6. Tırmıkçığlu Z. Drug use in pregnant women infected with COVID-19. Anatolian Clinic Journal of Medical Sciences 2020;25(Suppl 1):51-8.

7. Costedoat-Chalumeau N, Amoura Z, Duhaut P, Huong DL, Sebbough D, Wechsler B, et al Safety of hydroxychloroquine in pregnant patients with connective tissue diseases: a study of one hundred thirty-three cases compared with a control group. Arthritis Rheum 2003;48:3207-11.

8. Motta M, Tincani A, Faden D, Zinzini E, Lojacono A, Marchesi A, et al. Follow-up of infants exposed to hydroxychloroquine given to mothers during pregnancy and lactation. J Perinatol 2005;25:86-9.
9. Parke A, West B. Hydroxychloroquine in pregnant patients with systemic lupus erythematosus. J Rheumatol 1996;23:1715-8.

10. Hart CW, Naunton RF. The ototoxicity of chloroquine phosphate. Arch Otolaryngol 1964;80:407-12.

11. Cimaz R, Brucato A, Meregalli E, Muscará M, Sergi P. Electroretinograms of children born from mothers treated with hydroxychloroquine (HCQ) during pregnancy and breast-feeding. Lupus 2004; 13: 755.

12. Klinger G, Morad Y, Westall CA, Laskin C, Spitzer KA, Koren $\mathrm{G}$, et al. Ocular toxicity and antenatal exposure to chloroquine or hydroxychloroquine for rheumatic diseases. Lancet 2001;358:813-4.

13. Osadchy A, Ratnapalan T, Koren G. Ocular toxicity in children exposed in utero to antimalarial drugs: review of the literature. J Rheumatol 2011;38:2504-8.

14. Sperber K, Hom C, Chao CP, Shapiro D, Ash J. Systematic review of hydroxychloroquine use in pregnant patients with autoimmune diseases. Pediatr Rheumatol Online J 2009;7:9.

15. Kaplan YC, Ozarfati J, Nickel C, Koren G. Reproductive outcomes following hydroxychloroquine use for autoimmune diseases: A systematic review and meta-analysis. Br J Clin Pharmacol 2015; 173: 1132-41.

16. Götestam Skorpen C, Hoeltzenbein M, Tincani A, Fischer-Betz R, Elefant E, Chambers C, et al. The EULAR points to consider for use of antirheumatic drugs before pregnancy, and during pregnancy and lactation. Ann Rheum Dis 2016;75:795-810.

17. Centers for Disease Control and Prevention. CDC Yellow Book 2020: Health Information for International Travel. New York: Oxford University Press; 2019.

18. Cimaz R, Brucato A, Meregalli E, Muscará M, Sergi P. Electroretinograms of children born to mothers treated with hydroxychloroquine during pregnancy and breast-feeding: comment on the article by Costedoat-Chalumeau et al. Arthritis Rheum 2004;50:3056-7.

19. Motta M, Tincani A, Faden D, Zinzini E, Lojacono A, Marchesi A, et al. Follow-up of infants exposed to hydroxychloroquine given to mothers during pregnancy and lactation. J Perinatol 2005;25:86-9.

20. Peng W, Liu R, Zhang L, Fu Q, Mei D, Du X. Breast milk concentration of hydroxychloroquine in Chinese lactating women with connective tissue diseases. Eur J Clin Pharmacol 2019;75:154753.

21. Costedoat-Chalumeau N, Amoura Z, Aymard G, Le TH, Wechsler B, Vauthier D, et al. Evidence of transplacental passage of hydroxychloroquine in humans. Arthritis Rheum 2002;46:1123-4.

22. Kavanaugh A, Cush JJ, Ahmed MS, Bermas BL, Chakravarty E, Chambers C, et al. Proceedings from the American College of Rheumatology Reproductive Health Summit: The management of fertility, pregnancy, and lactation in women with autoimmune and systemic inflammatory diseases. Arthritis Care Res (Hoboken) 2015;67:313-25.

23. Flint J, Panchal S, Hurrell A, van de Venne M, Gayed M, Schreiber $\mathrm{K}$, et al. BSR and BHPR guideline on prescribing drugs in pregnancy and breastfeeding-Part I: standard and biologic disease modifying anti-rheumatic drugs and corticosteroids. Rheumatology (Oxford) 2016;55:1693-7. 
24. Sammaritano LR, Bermas BL, Chakravarty EE, Chambers C, Clowse MEB, Lockshin MD, et al. 2020 American College of Rheumatology Guideline for the management of reproductive health in rheumatic and musculoskeletal diseases. Arthritis Rheumatol 2020;72:529-56.

25. Centers for Disease Control and Prevention. CDC Yellow Book 2020: Health information for international travel. New York: Oxford University Press 2019.

26. Marzolini C, Rudin C, Decosterd LA, Telenti A, Schreyer A, Biollaz $\mathrm{J}$, et al. Transplacental passage of protease inhibitors at delivery. AIDS 2002;16:889-93.

27. Ivanovic J, Nicastri E, Anceschi MM, Ascenzi P, Signore F, Pisani $\mathrm{G}$, et al. Transplacental transfer of antiretroviral drugs and newborn birth weight in HIV-infected pregnant women. Curr HIV Res 2009;7:620-5.

28. Simon A, Warszawski J, Kariyawasam D, Le Chenadec J, Benhammou $\mathrm{V}$, Czernichow P, et al. Association of prenatal and postnatal exposure to lopinavir-ritonavir and adrenal dysfunction among uninfected infants of HIV-infected mothers. JAMA 2011;306:70-8.

29. Antiretroviral pregnancy registry Interim report for. 1 January 1989 -31 July 2020. Wilmington, NC: Registry Coordinating Center; 2019.

30. Sibiude J, Mandelbrot L, Blanche S, Le Chenadec J, Boullag-Bonnet $\mathrm{N}$, Faye A, et al. Association between prenatal exposure to antiretroviral therapy and birth defects: an analysis of the French perinatal cohort study (ANRS CO1/CO11). PLoS Med 2014;11:1001635.

31. Tookey PA, Thorne C, van Wyk J, Norton M. Maternal and foetal outcomes among 4118 women with HIV infection treated with lopinavir/ritonavir during pregnancy: analysis of population-based surveillance data from the national study of HIV in pregnancy and childhood in the United Kingdom and Ireland. BMC Infect Dis 2016;16:65.

32. Wang L, Zhao H, Cai W, Tao J, Zhao Q, Sun L, et al. Risk factors associated with preterm delivery and low delivery weight among HIVexposed neonates in China. Int J Gynaecol Obstet 2018;142:300-7.

33. Guideline: Updates on HIV and Infant Feeding: The Duration of Breastfeeding, and Support from Health Services to Improve Feeding Practices Among Mothers Living with HIV. Geneva: World Health Organization; 2016.

34. Gandhi M, Mwesigwa J, Aweeka F, Plenty A, Charlebois E, Ruel TD, et al. Hair and plasma data show that lopinavir, ritonavir, and efavirenz all transfer from mother to infant in utero, but only efavirenz transfers via breastfeeding. J Acquir Immune Defic Syndr 2013;63:578-84.

35. Ramirez-Ramirez A, Sanchez-Serrano E, Loaiza-Flores G, PlazolaCamacho N, Rodriguez-Delgado RG, Figueroa-Damian R, et al. Simultaneous quantification of four antiretroviral drugs in breast milk samples from HIV-positive women by an ultra-high performance liquid chromatography tandem mass spectrometry (UPLCMS/ MS) method. PLoS One 2018;13:e0191236.

36. Oumar AA, Bagayoko-Maiga K, Bahachimi A, Maiga M, Cere $\mathrm{MC}$, Diarra Z, et al. Efavirenz and lopinavir levels in HIV-infected women and their nursing infants, in mali. J Pharmacol Exp Ther 2018;366:479-84.
37. Heikkinen T, Laine K, Neuvonen PJ, Ekblad U. The transplacental transfer of the macrolide antibiotics erythromycin, roxithromycin and azithromycin. BJOG 2000;107:770-5.

38. Savitcheva AM, Tchkhartishvili MG, Arzhanova O, Drobchenko SN. The course and outcome of pregnancy in women with chlamydial infection. J Perinat Med 2001;29(Suppl 1): 372.

39. Rahangdale L, Guerry S, Bauer HM, Packel L, Rhew M, Baxter R, et al. An observational cohort study of chlamydia trachomatis treatment in pregnancy. Sex Transm Dis 2006;33:106-10.

40. Cooper WO, Hernadez-Diaz S, Arbogast PG, Dudley JA, Dyer SM, Gideon PS, et al. Antibiotics potentially used in response to bioterrorism and major congenital malformations. Pharmaco Epidemiol Drug Saf 2006; 15(Suppl 1): S6- S7.

41. Bar-Oz B, Weber-Schoendorfer C, Berlin M, Clementi M, Di Gianantonio E, de Vries L, et al. The outcomes of pregnancy in women exposed to the new macrolides in the first trimester: A prospective, multicentre, observational study. Drug Saf 2012;35:58998.

42. Cooper WO, Hernandez-Diaz S, Arbogast PG, Dudley JA, Dyer SM, Gideon PS, et al. Antibiotics potentially used in response to bioterrorism and the risk of major congenital malformations. Paediatr Perinat Epidemiol 2009;23:18-28.

43. Muanda FT, Sheehy O, Bérard A. Use of antibiotics during pregnancy and risk of spontaneous abortion. CMAJ 2017;189:625-33.

44. Kelsey JJ, Moser LR, Jennings JC, Munger MA. Presence of azithromycin breast milk concentrations: A case report. Am J Obstet Gynecol 1994;170:1375-6.

45. Sørensen HT, Skriver MV, Pedersen L, Larsen H, Ebbesen F, Schønheyder HC. Risk of infantile hypertrophic pyloric stenosis after maternal postnatal use of macrolides. Scand J Infect Dis 2003;35:104-6.

46. Lund M, Pasternak B, Davidsen RB, Feenstra B, Krogh C, Diaz LJ, et al. Use of macrolides in mother and child and risk of infantile hypertrophic pyloric stenosis: nationwide cohort study. BMJ 2014;348:1908.

47. Goldstein LH, Berlin M, Tsur L, Bortnik O, Binyamini L, Berkovitch M. The safety of macrolides during lactation. Breastfeed Med 2009;4:197-200.

48. Sutton AL, Acosta EP, Larson KB, Kerstner-Wood CD, Tita AT, Biggio JR. Perinatal pharmacokinetics of azithromycin for cesarean prophylaxis. Am J Obstet Gynecol 2015;212:812.

49. Abdellatif M, Ghozy S, Kamel MG, Elawady SS, Ghorab MME, Attia AW, et al. Association between exposure to macrolides and the development of infantile hypertrophic pyloric stenosis: A systematic review and meta-analysis. Eur J Pediatr 2019;178:301-14.

50. Almaramhy HH, Al-Zalabani AH. The association of prenatal and postnatal macrolide exposure with subsequent development of infantile hypertrophic pyloric stenosis: a systematic review and metaanalysis. Ital J Pediatr 2019;45:20. 